\title{
Synthesis of Novel Fullerene-Porphyrin Conjugates for the Formation of Langmuir Monolayers
}

\author{
Ekaterina S. Zyablikova, ${ }^{a}{ }^{2}$ atal'ya A. Bragina, ${ }^{a}$ Andrey F. Mironov, ${ }^{a}$ \\ Daria A. Silant'eva, ${ }^{\text {b }}$ and Sofia L. Selektor ${ }^{b}$ \\ Dedicated to Academician Aslan Tsivadze on the occasion of his $70^{\text {th }}$ Anniversary
}

${ }^{\mathrm{a}}$ Department of Chemistry and Technology of Biologically Active Compounds, Lomonosov Moscow State University of Fine

Chemical Technologies, 119571 Moscow, Russian Federation.

E-mail: e.s.krutikova@gmail.com

${ }^{\mathrm{b}}$ Frumkin Institute of Physical Chemistry and Electrochemistry of the Russian Academy of Sciences, 119071 Moscow,

Russian Federation

E-mail:sofs@list.ru

The conjugates of $C_{60}$ fullerene and lipophilic meso-aryl substituted porphyrins with terminal long chains are prepared and used to form Langmuir monolayers at the air/water interface.

Keywords: Fullerenes, meso-aryl substituted porphyrins, fullerene-porphyrin conjugates, Langmuir monolayers.

\section{Синтез новых фуллерен-порфириновых конъюгатов Аля формирования монослоев Аенгмюра}

\author{
Е. С. Зябликова, ${ }^{a}$ Н. А. Брагина, ${ }^{a}$ А. Ф. Миронов, ${ }^{a}$ А. А. Силантьева, ${ }^{\mathrm{b}}$ \\ С. $\lambda$. Селектор $^{b}$
}

Посвящается акаgемику А. Ю. Циваgзе по случаю его 70-летнего юбилея

\author{
${ }^{\mathrm{a}}$ Московский государственный университет тонких химических технологий имени М.В. Ломоносова, 119571 Москва, Россия \\ E-mail: e.s.krutikova@gmail.com \\ ' Институт физической химии и электрохимии имени А. Н. Фрумкина РАН, 119071 Москва, Россия \\ E-mail:sofs@list.ru
}

\begin{abstract}
Осуществлен синтез конъюгатов на основе фуллерена $C_{60}$ и липофильных мезо-арилпорфиринов с длинноцепными заместителями для получения на их основе монослоев Ленгмюра.
\end{abstract}

Ключевые слова: Фуллерены, мезо-арилзамещенные порфирины, фуллерен-порфирин конъюгаты, монослои Ленгмюра.

\section{Introduction}

In recent years there has been much research activity focused on the fullerene-porphyrin conjugates known for unique electronic properties that allow using these assemblies in various optoelectronic and photoelectrical devices for diverse applications and particularly in photovoltaics, solar batteries, in the construction of photosynthetic models. ${ }^{[1-5]}$ The structures in which the conjugated porphyrin absorbs light in the UV-vis spectral range and acts as an electron donor while the fullerene having weak light absorption acts as an electron acceptor are of special importance. ${ }^{[6-7]}$ Irradiation of such dyads yields a radical ion pair, the charge-separated state lifetime of which exceeds one of the known donor-acceptor systems by 
several orders of magnitude..$^{[8-12]}$ The energy of the chargeseparated state can be converted into chemical or electrical energy through vectorial electron transfer. To accomplish this the donor-acceptor molecules must be assembled into a molecular monolayer with a unidirectional orientation. Desired arrangement of porphyrin-fullerene donor-acceptor dyads can be realized in the Langmuir monolayer. ${ }^{[13-17]}$

Since the formation of high ordered Langmuir monolayers at air/water interface are favored by using porphyrins substituted by long hydrophobic side chains, we have synthesized conjugates based on $\mathrm{C}_{60}$ fullerene and lypophilic meso-arylsubstituted porphyrins with long chain alkyl groups of 6, 14, and 18 carbon atoms (Figure 1).

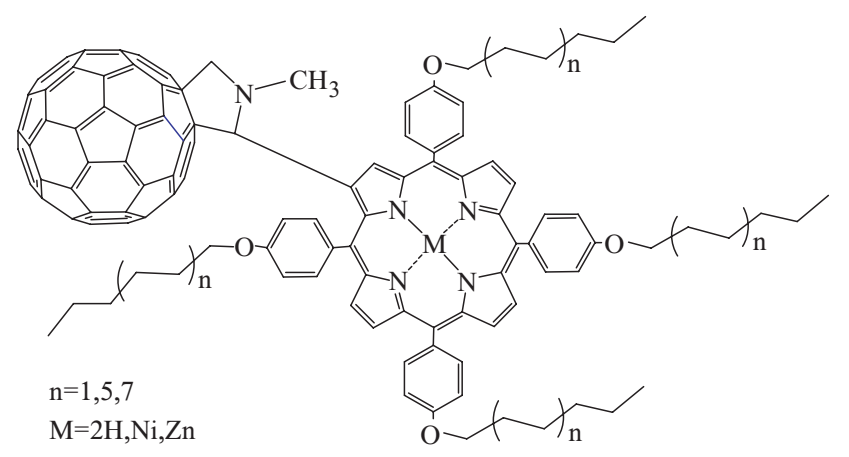

Figure 1. Structure of fullerene-porphyrin conjugates.

\section{Results and Discussion}

Among the main approaches for preparation of porphyrin conjugates with $\mathrm{C}_{60}$ (namely, the [3+2] BingelHirsch cyclopropanation of $\mathrm{C}_{60}$ fullerene and the [4+2] Diels-Alder cycloaddition), the [3+2] cyclopropanation is considered as the most effective synthetic route to covalently linked conjugates. ${ }^{[18-24]}$

Thus to derive the fullerene-porphyrin conjugates with long chain alkyl substituents we employed the Prato reaction that is 1,3-dipolar cycloaddition to the double bond in a 6,6 ring position in a fullerene of azomethine ylide generated by the condensation of an $\alpha$-amino acid and an aldehyde. ${ }^{[25-26]}$

The reaction offers the following advantages:

- The condensation yields single 6,6-closed isomers;

- Various $\alpha$-amino acids and aldehydes can be easily obtained from commercially available precursors;
- The intermediate ylides may be synthesized starting with diverse aldehydes to afford a variety of functionalized fulleropyrrolidinoporphyrins.

In this work, we used mono- $\beta$ formyltetraphenylporphyrins with the long chain alkyl groups at the $p$-position of meso-phenyl moieties.

$\mathrm{C}_{60}$ was bound to formylporphyrins $\mathbf{1 a}, \mathbf{b}, \mathbf{c}$ by condensation with $\mathrm{N}$-methylglycine in dry toluene under argon, reaction time was $20 \mathrm{~h}$, TLC control (hexane:toluene) (Scheme 1). The reaction mixture was cooled and the solvent was removed in vacuo. The produced conjugates $\mathbf{3 a}, \mathbf{b}, \mathbf{c}$ were isolated by column chromatography on silica gel (hexane:toluene $=3: 1$, hexane:chloroform $=3: 1$ ) in 25 $27 \%$ yield. Long alkyl chains attached onto the periphery of the porphyrin core provide good solubility of fullereneporphyrin conjugates in methylene chloride, which makes further handling of the synthesized products much easier.

The synthesized dyads were characterized by IR, UVvis, ${ }^{13} \mathrm{C}$ NMR, ${ }^{1} \mathrm{H}$ NMR spectroscopy, and mass-spectrometry. The absorption spectra of $\mathbf{3 a}, \mathbf{b}, \mathbf{c}$ show the hypsochromic shift of the Soret band towards $429 \mathrm{~nm}$. Proton resonances shifted 5.46 ppm (1H, s, NCH), $4.68\left(1 \mathrm{H}, \mathrm{d}, \mathrm{NCH}_{2}\right), 3.83$ ppm $(1 \mathrm{H}, \mathrm{d}$, $\left.\mathrm{NCH}_{2}\right)$ and $2.54 \mathrm{ppm}\left(3 \mathrm{H}, \mathrm{s}, \mathrm{NCH}_{3}\right)$ in the ${ }^{1} \mathrm{H}$ NMR spectrum of $\mathbf{3 a}$ indicate the formation of pyrrolidine ring. The signals at 158.45-110.88 ppm observed in ${ }^{13} \mathrm{C}$ NMR spectrum of $\mathbf{1 a}$ are from the fullerene fragment of the dyad, and those at 66.92, $67.09,67.36,68.89,38.38 \mathrm{ppm}$ belong to pyrrolidine ring. The MALDI peak at $\mathrm{m} / z 1792.33$ in the mass spectrum of 3a corresponds to the molecular ion of the dyad.

The nickel complexes of fullerene-porphyrin conjugates were prepared starting from formylporphyrins $\mathbf{2 a , b}, \mathbf{c}$ analogously to conjugates $\mathbf{3 a}, \mathbf{b}, \mathbf{c}$. In this case the yield was somewhat lower but it was found to increase with alkyl chain length.

The Soret band in the absorption spectra is shifted towards 426-427 $\mathrm{nm}$. The ${ }^{1} \mathrm{H}$ NMR spectrum of 4 a contains signals from pyrrolidine ring shifted $5.46 \mathrm{ppm}(1 \mathrm{H}, \mathrm{s}, \mathrm{NCH})$, $4.71\left(1 \mathrm{H}, \mathrm{d}, \mathrm{NCH}_{2}\right), 3.86 \mathrm{ppm}\left(1 \mathrm{H}, \mathrm{d}, \mathrm{NCH}_{2}\right)$, and 2.57 ppm $\left(3 \mathrm{H}, \mathrm{s}, \mathrm{NCH}_{3}\right) .{ }^{13} \mathrm{C}$ NMR spectrum of $4 \mathbf{a}$ shows signals from fullerene $\mathrm{sp}^{2} \mathrm{C}$ atoms at $159.80-113.12 \mathrm{ppm}$ and from pyrrolidine $\mathrm{sp}^{3} \mathrm{C}$ atoms at $66.89,67.01,67.37,38.5 \mathrm{ppm}$.

The synthesized fullerene-porphyrin conjugates were used to derive the corresponding zinc complexes $\mathbf{5 a , b , c}$ (Scheme 2). Treatment of 3a,b,c with zinc acetate in chloroform/methanol mixture afforded zinc complexes of the dyads, the formation of which was confirmed

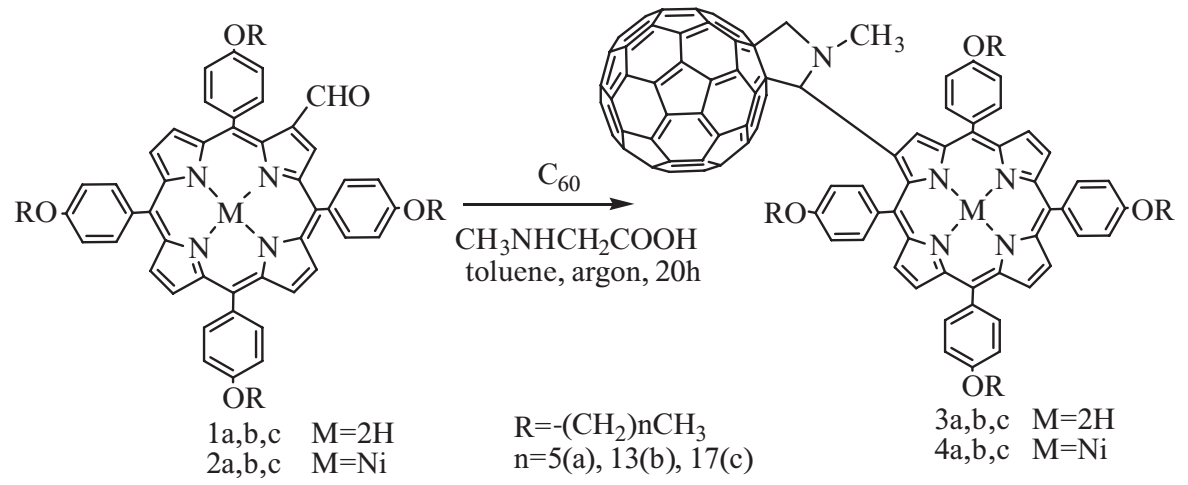

Scheme 1. Synthesis of fullerene-porphyrin conjugates. 


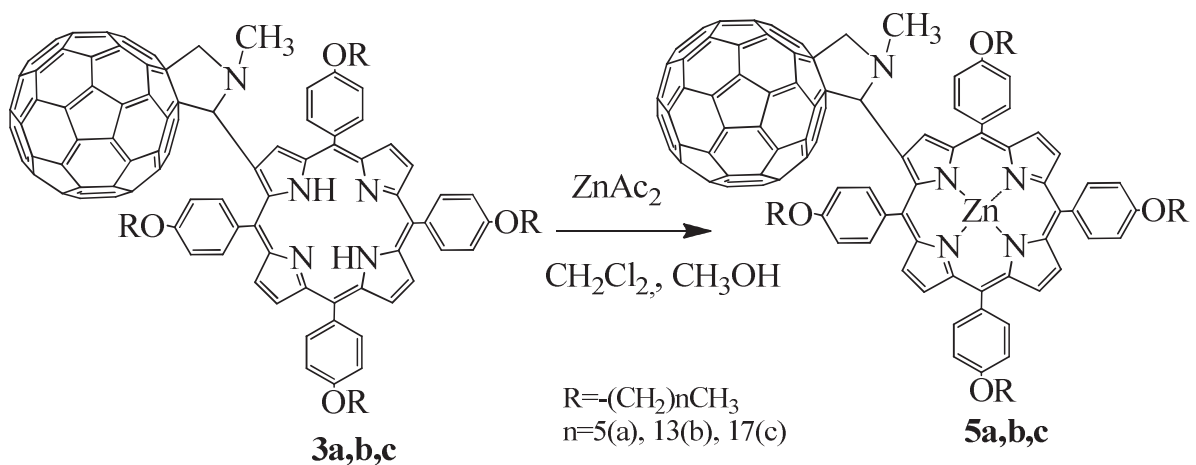

Scheme 2. Synthesis of zinc complexes of porphyrin-fullerene conjugates.

spectrophotometrically. The electronic absorption spectra of metalated 5a,b,c feature the prominent Soret band at $430 \mathrm{~nm}$ and one $Q$ band at $555 \mathrm{~nm}$ indicative of insertion of the metal into the porphyrin ring. The obtained metalloporphyrins were dissolved in chloroform and precipitated by addition of heptane. Zinc complexes were isolated in $92-95 \%$ yield.

Considering the produced dyads $\mathbf{3 a}, \mathbf{b}, \mathbf{c}$ and their nickel complexes $\mathbf{4 a}, \mathbf{b}, \mathbf{c}$ and zinc complexes $\mathbf{5 a}, \mathbf{b}, \mathbf{c}$, we examined the possibility of forming Langmuir monolayers on the aqueous subphase. It was found that the dyads $\mathbf{3 a}, \mathbf{b}, \mathbf{c}$ and their nickel complexes $\mathbf{4 a}, \mathbf{b}, \mathbf{c}$ and zinc complexes $\mathbf{5 a}, \mathbf{b}, \mathbf{c}$ are able to form stable monolayers at air/water interface.

Formation of Langmuir monolayers as well as compression experiments were performed with the KSV (KSV Mini, Finland) system equipped with a moving barrier and a Wilhelmi plate (accuracy $0.05 \mathrm{mN} / \mathrm{m}$ ). Water surface area between the barriers was $273.0 \mathrm{~cm}^{2}$ (length $-36.4 \mathrm{~cm}$, width $-7.5 \mathrm{~cm})$. The in situ absorption and fluorescence spectra for the monolayers on the water surface under compression were recorded with the AvaSpec-2048 fiber optic spectrometer (Netherlands). ${ }^{[27-28]}$ The subphase was deionized water. Chloroform of analytical grade (Merck) was used for solution preparation and as a spreading solvent. Exposition time for solvent evaporation was $15 \mathrm{~min}$. Monolayers were compressed at the rates of $2 \mathrm{~cm}^{2} / \mathrm{min}$.
Surface pressure (surface pressure versus water area available per molecule) isotherms were measured to study the possibility of forming stable monolayers at the air/water interface. For fullerene-porphyrin dyad $\mathbf{3 b}$ (Figure 2a), the curve shows a classical shape with three distinct regions corresponding to the phase transition of the monolayer. Sequential compression of the monolayer changes the structure of monolayer films, which passes through a series of two-dimensional states, conventionally designated as the state of gas, liquid, and solid. When the available area is large, the monolayer can be regarded as a two-dimensional gas (region 1). If the surface area of the monolayer is reduced by a barrier system, as early as at the surface pressures of $2-3 \mathrm{mN} / \mathrm{m}$ the isotherm bends upward as the monolayer undergoes a transition to the liquid-expanded state (region 2). A less pronounced bend in the isotherm at $10-15 \mathrm{mN} / \mathrm{m}$ marks the transformation to a more ordered liquid-condensed state. Upon further compression to 50$55 \mathrm{mN} / \mathrm{m}$ molecules form densely packed monolayer, that corresponds to the solid state film (region 3). A high degree of order in the monolayer is suggested by the high surface pressure and rather high area at which monolayer collapses. Good experimental reproducibility and the identical surface pressure isotherms obtained for the monolayers spread from the chloroform solutions of different volumes mean that a)

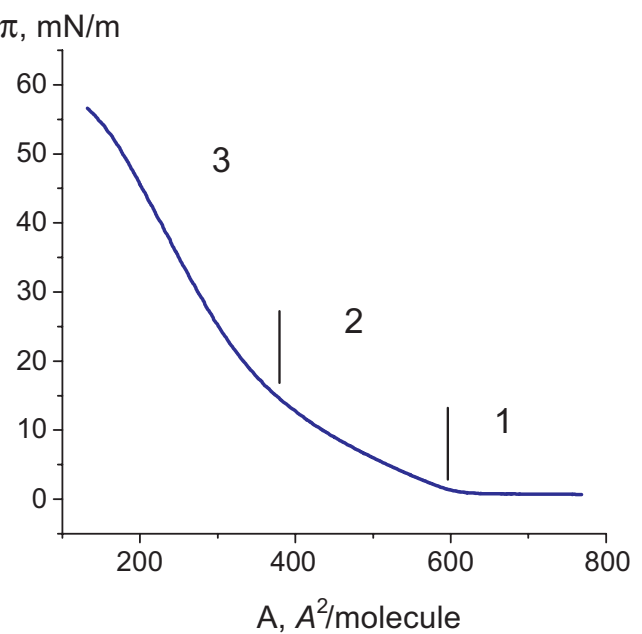

b)

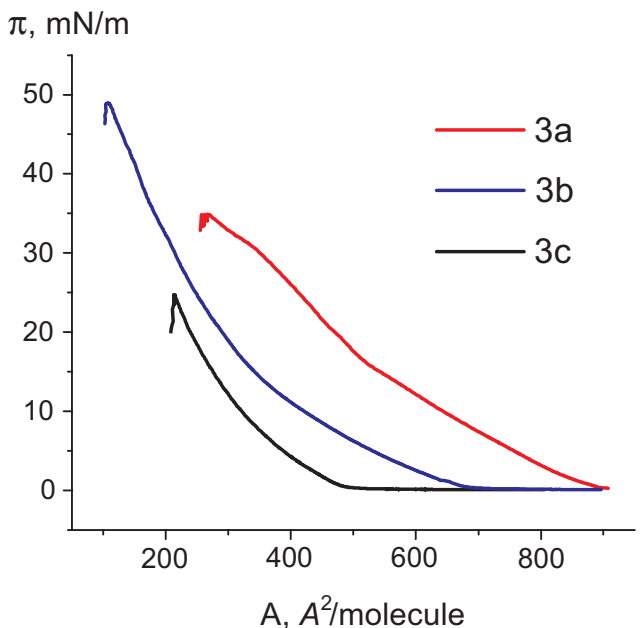

Figure 2. Isotherms of monolayer compression at the air/water interface at $\left.\left.\mathrm{T}=27^{\circ} \mathrm{C}: \mathrm{a}\right) \mathbf{3 b}\left(500 \mathrm{mkl}, 5 \cdot 10^{-6} \mathrm{M}\right), \mathrm{b}\right) \mathbf{3 a}\left(625 \mathrm{mkl}, 1 \cdot 10^{-5} \mathrm{M}\right)$, $\mathbf{3 b}\left(625 \mathrm{mkl}, 1 \cdot 10^{-5} \mathrm{M}\right)$, and $\mathbf{3 c}\left(500 \mathrm{mkl}, 1 \cdot 10^{-5} \mathrm{M}\right) ; \pi$ is the surface pressure, $A$ is area per molecule. 
a)

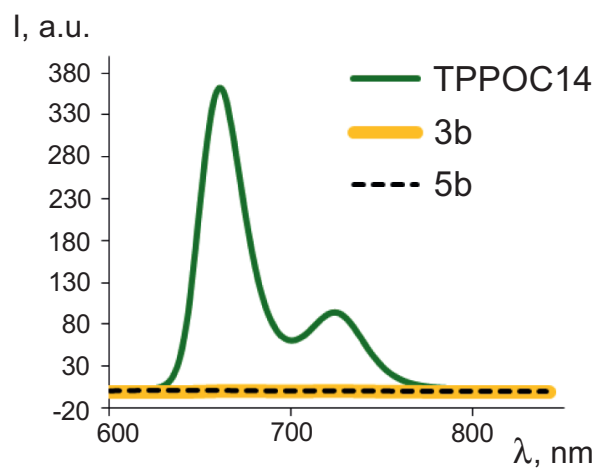

b)

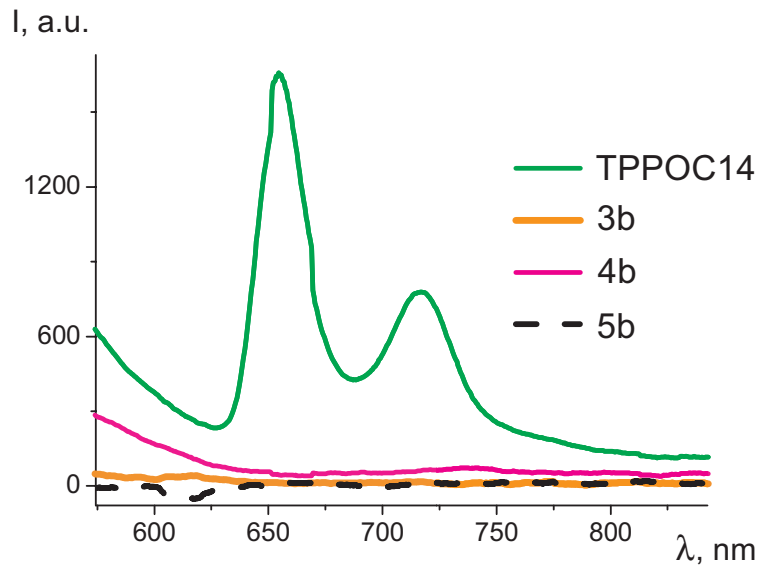

Figure 3. a) Fluorescence spectra of solution of dyad $\mathbf{3 b}\left(1 \cdot 10^{-6} \mathrm{M}\right), \mathbf{5 b}\left(1 \cdot 10^{-6} \mathrm{M}\right)$ and porphyrin TPPOC14 $\left(\mathrm{CHCl}_{3}\right)$, b) fluorescence spectra of the monolayers of dyad $\mathbf{3 b}\left(5 \cdot 10^{-6} \mathrm{M}, 500 \mathrm{mkl}\right), \mathbf{4 b}\left(1 \cdot 10^{-5} \mathrm{M}, 500 \mathrm{mkl}\right), \mathbf{5 b}\left(1 \cdot 10^{-5} \mathrm{M}, 500 \mathrm{mkl}\right)$ and porphyrin TPPOC $14\left(1 \cdot 10^{-5}\right.$, $450 \mathrm{mkl} \mathrm{M}$ ), (surface pressure $25 \mathrm{mN} / \mathrm{m}$ ). Wavelength $430 \mathrm{~nm}$.

lipophilic molecules spread uniformly on water without selfaggregation thus proving the system stability and, therefore, we managed to get a true Langmuir monolayers.

Comparing the surface pressure isotherms for the monolayers of $\mathbf{3 a}, \mathbf{3} \mathbf{b}$, and $\mathbf{3} \mathbf{c}$ bearing hydrocarbon chains of different lengths (Figure 2b), it expectedly turns out that the most stable monolayer is formed by dyad $\mathbf{3 b}$ with pendant tetradecyl groups due to the high pressure of the collapse, according to $\pi$ - $A$-isotherm.

For dyad $\mathbf{3 b}$ and $\mathbf{5 b}$ solutions in $\mathrm{CHCl}_{3}$ fluorescence quenching was much stronger compared to parent 5,10,15,20tetra(4-tetradecyloxyphenyl)porphyrin TPPOC14 (Figure 3a). Concerning the Langmuir monolayers of dyads $\mathbf{3 b}, \mathbf{4 b}$ and $\mathbf{5 b}$ the intensive reduction of fluorescence intensity compared to the monolayer of TPPOC14 was also observed (Figure 3b).

The absorption spectrum of molecular monolayer is highly sensitive to the aggregation type of fullereneporphyrin adducts. Hence the behavior of the monolayers under 2D compression on the water surface in situ was studied spectrometrically. The absorption spectra of fullerene-porphyrin conjugates $\mathbf{3 b}$ and $\mathrm{Ni}$, Zn-complexes 4b, 5b solutions in $\mathrm{CHCl}_{3}$ are shown in Figure $4 \mathrm{a}$. The

a)

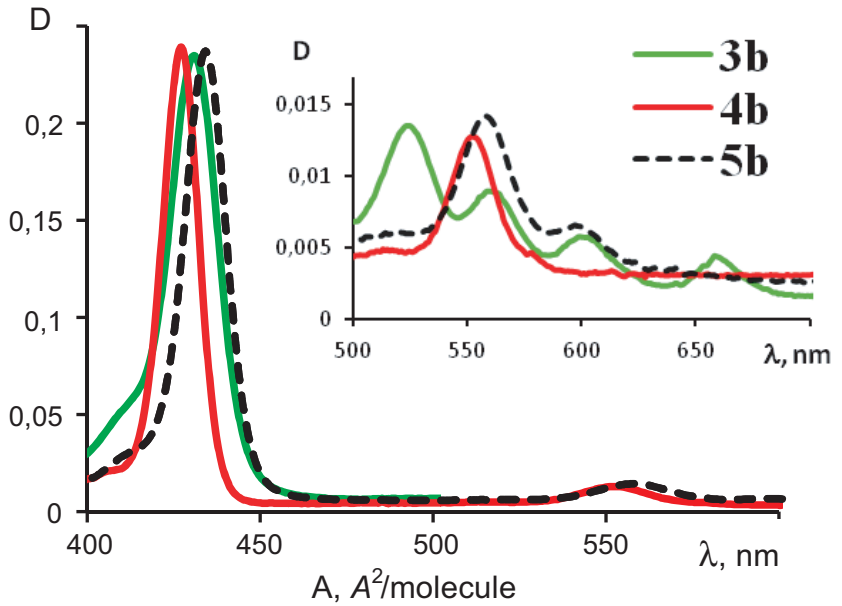

absorption spectrum of the $\mathbf{3 b}, \mathbf{4 b}$ and $\mathbf{5 b}$ monolayers is characterized by distinct Soret band at $440 \mathrm{~nm}$ (Figure $5 \mathrm{a}, \mathrm{b}, \mathrm{c})$. The absorption spectra of $\mathbf{4 b}$ and $\mathbf{5 b}$ monolayers have a broad band with the maximum at 550-560 nm corresponding to one $Q$ band. The Langmuir monolayer of dyad $\mathbf{3 b}, \mathbf{4 b}$ and $\mathbf{5 b}$ exhibited a significant increase in the absorption intensity with the surface pressure within 2 to $25 \mathrm{mN} / \mathrm{m}$ range, which indicates the formation of a highly ordered monolayer on deionized water (Figure 5a,b,c). Bathochromic shift of the Soret band of the fullereneporphyrin conjugates of 2-3 nm implies that no aggregation occurs in this case. The mean molecular area-surface pressure isotherms of the dyad $\mathbf{3 b}, \mathbf{4 b}$, and $\mathbf{5 b}$ monolayers on the water surface are presented in Figure $4 \mathrm{~b}$.

The similar results were obtained for dyads $\mathbf{3 a}, \mathbf{c}$ and their nickel complexes $\mathbf{4 a}, \mathbf{c}$ and zinc complexes $\mathbf{5 a , c}$.

Thus, addition of terminal long chain hydrophobic alkyl groups to the porphyrin-fullerene molecules promotes the formation of highly ordered Langmuir monolayers at the air/water interface. These monolayers can be transferred onto solid substrates, which is essential for their further use in optoelectronics.

b)

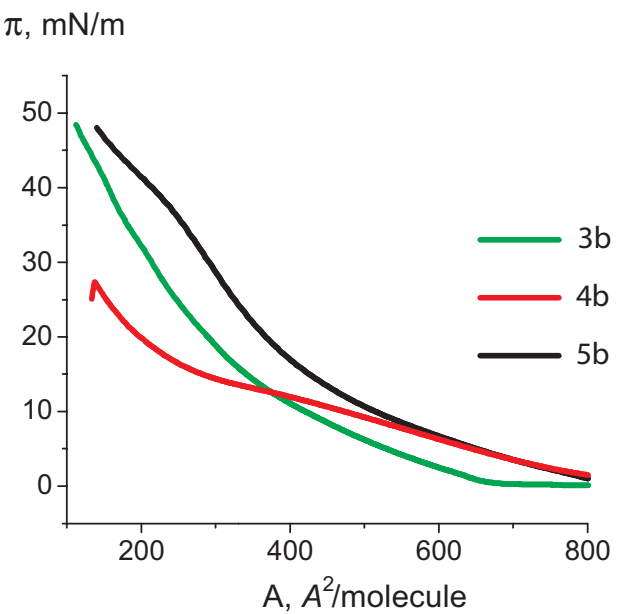

Figure 4. a) The absorption spectra of dyad $\mathbf{3 b}\left(1 \cdot 10^{-6} \mathrm{M}\right), \mathbf{4 b}\left(1 \cdot 10^{-6} \mathrm{M}\right)$ and $\mathbf{5 b}\left(1 \cdot 10^{-6} \mathrm{M}\right)$ : solutions in $\mathrm{CHCl}_{3}$. b) Isotherms of monolayer compression at the air/water interface at $27^{\circ} \mathrm{C}: \mathbf{3 b}\left(5 \cdot 10^{-6} \mathrm{M}, 500 \mathrm{mkl}\right), \mathbf{4 b}\left(1 \cdot 10^{-5} \mathrm{M}, 500 \mathrm{mkl}\right), \mathbf{5 b}\left(1 \cdot 10^{-5} \mathrm{M}, 500 \mathrm{mkl}\right)$. 
a)

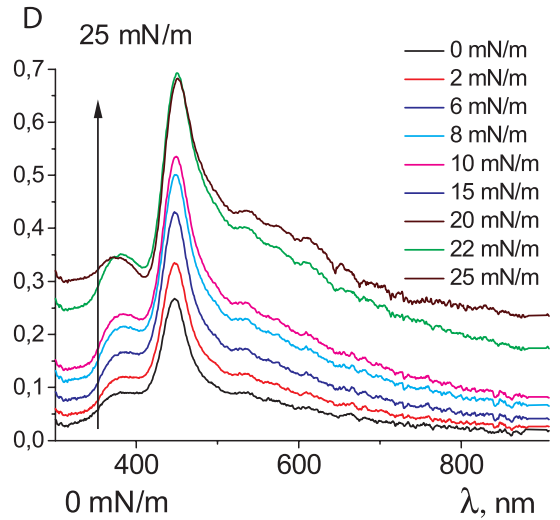

b)

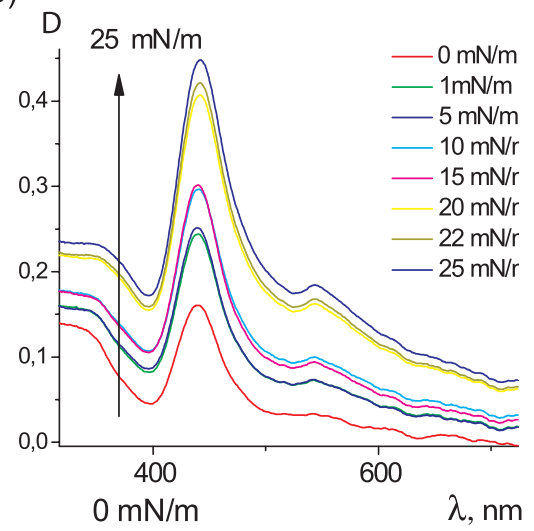

c)

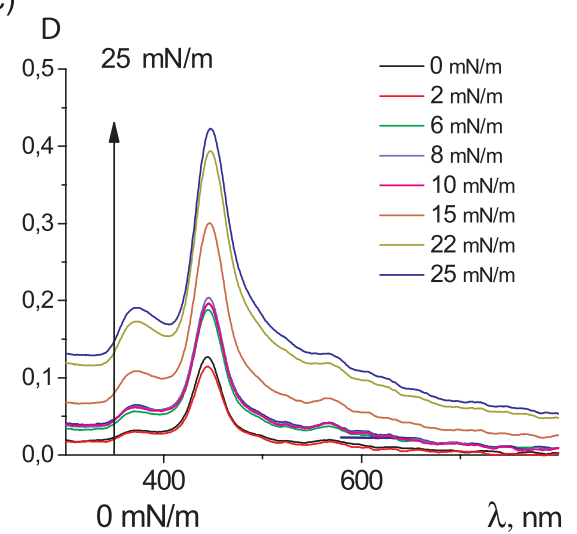

Figure 5. The absorption spectra of monolayer: a) $3 \mathbf{b}\left(1 \cdot 10^{-5} \mathrm{M}, 625 \mathrm{mkl}\right)$; b) $4 \mathbf{b}\left(1 \cdot 10^{-5} \mathrm{M}, 500 \mathrm{mkl}\right)$; c) $\mathbf{5 b}\left(2.5 \cdot 10^{-5} \mathrm{M}, 250 \mathrm{mkl}\right)$. Arrows indicate the direction of the surface pressure gradient.

\section{Conclusion}

New fullerene-porphyrin conjugates bearing terminal hydrocarbon long chains were synthesized and metalated to yield zinc and nickel complexes. The prepared fullereneporphyrin adducts form highly ordered Langmuir monolayers on the water subphase. The most stable Langmuir monolayers are produced by the conjugates with tetradecyl side chains attached to the porphyrin ring. It is necessary to note that such monolayers retain the optical and fluorescence characteristics of new compounds in chloroform solutions.

\section{References}

1. Langa F., Nierengarten J.-F. Fullerenes: Principles and Applications. Cambridge: The Royal Society of Chemistry, 2007. 398 p.

2. Rosen B.M., Wilson C.J., Wilson D.A., Peterca M., Imam M.R., Percec V. Chem. Rev. 2009, 109, 6275-6540.

3. Sidorov L.N., Yurovskaya N.A., Borschevskii A.Yu., Trushkov I.V., Ioffe I.N. Fullereny [Fullerenes]. Moscow: Publishers: "Ekzamen", 2005. 688 p. (in Russ.).

4. Rezayat S.M., Boushehri S.V.S., Salmanian B., Omidvari A.H., Tarighat S., Esmaeili S., Sarkar S., Amirshahi N., Alyautdin R.N., Orlova M.A., Trushkov I.V., Buchachenko A.L., Liu K.C., Kuznetsov D.A. Eur. J. Med. Chem. 2009, 44, 1554-1569.

5. Razumov V.F., Efimov O.N., Kaplunov M.T., Klyuev M.V., Klyueva M.E., Lomova T.N., Tarasov B.P., Troshin P.A., Yarmolenko O.B., Nanostrukturirovannye materialy dlya sistem zapasaniya i preobrazovaniya energii [Nanostructured Materials for Energy Storage and Processing Systems]. Ivanovo State University, 2007. 296 p. (in Russ.).

6. Kahnt A., Kärnbratt J., Esdaile L. J., Hutin M., Sawada K., Anderson H. L., Albinsson B. J. Am. Chem. Soc. 2011, 133, 9863-9871.

7. Li W.-S., Aida T. Chem. Rev. 2009, 109, 6047-6076.

8. Guldi D.M. Fullerenes: From Synthesis to Optoelectronic Properties. Kluwer Academic Publishers: Dordrecht, The Netherlands, 2002. p. 163-212.

9. Guldi D.M., Rahman G.M.A., Sgobba V., Ehli C. Chem. Soc. Rev. 2006, 35, 471-487.
10. Molina-Ontoria A., Wielopolski M., Gebhardt J., Gouloumis A., Clark T., Guldi D. M., Mart N. J. Am. Chem. Soc. 2011 133, 2370-2373.

11. Choi M.-S., Aida T., Luo H., Araki Y., Ito O. Angew. Chem.Int. Ed. 2003, 42, 4060-4063.

12. Kuciauskas D., Liddell P.A., Lin S., Johnson T.E., Weghorn S.J., Lindsey J.S., Moore A.L., Moore T.A., Gust D. J. Am. Chem. Soc. 1999, 121, 8604-8614.

13. Vuorinen T., Kaunisto K., Tkachenko N.V. Langmuir $\mathbf{2 0 0 5}$, 21, 5383-5390.

14. Vivo P.A., Alekseev A.S., Kaunisto K., Pekkola O., Tolkki A., Chukharev V., Efimov A., Ihalainen P. Phys. Chem. Chem. Phys. 2010, 12, 12525-12532.

15. Lewandowska K., Bogucki A., Wrobel D., Graja A. J. Photochem. Photobiol. A: Chem. 2007, 188, 12-18.

16. Vuorinen T., Kaunisto K., Tkachenko N.V., Efimov A., Lemmetyinen H. J. Photochem. Photobiol. A: Chem. 2006, 178, 185-191.

17. Alekseev A.S., Tkachenko N.V., Efimov A.V., Lemmetyinen H. Zh. Fiz. Khimii 2010, 84, 1356-1367 (in Russ.).

18. Nagata N., Kuramochi Y., Kobuke Y. J. Am. Chem. Soc. 2009, 131, 10-11.

19. Souza F.D., Gadde S., Zandler M. E., Klykov A., El-Khouly M.E. Fujitsuka M., Ito O. J. Phys. Chem. A. 2002, 106, 12393-12404.

20. Schuster D.I., Li K., Guldi D.M., Palkar A., Echegoyen L., Stanisky C., Cross R. J., Niemi M., Tkachenko N.V., Lemmetyinen H. J. Am. Chem. Soc. 2007, 129, 15973-15982.

21. Lembo A., Tagliatesta P., Guldi D.M., Wielopolski M., Nuccetelli M. J. Phys. Chem. A. 2009, 113, 1779-1793.

22. Fazio M.A., Lee O.P., Schuster D.I. Org Lett. 2008, 10, 4979-4982.

23. Higashida S., Imahori H., Kaneda T., Sakata Y. Chem. Lett. 1998, 7, 605-606.

24. Carbonera D.V., Valentin M.D., Corvaja C., Agostini G., Giacometti G., Liddell P.A, Kuciauskas D., Moore A.L., Moore T.A., Gust D. J. Am. Chem. Soc. 1998, 120, 4398-4405.

25. Maggini M., Scorrano G. J. Am. Chem. Soc. 1993, 115, 9798-9799.

26. Drovetskaya T., Reed C.A., Boyd P. Tetrahedron Lett. 1995, 36, 7971-7974.

27. Stuchebrukov S.D., Selektor S.L., Silantieva D.A., Shokurov A.V. Prot. Met. Phys. Chem. Surf. 2013, 49 (in press).

28. Selector S., Fedorova O., Lukovskaya E., Anisimov A., Fedorov Y., Tarasova N., Raitman O., Fages F., Arslanov V. J. Phys. Chem. B. 2012, 116, 1482-1490. 